3. From: (Originating Organization)

Engineering Development

5. Proj./Prog./Dept./Div.:

Sol id Waste Management

8. Originator Remarks:

Approval by September 1, 1994.
Restoration Projects

6. Cog. Engr.:

R. S. McBeath
4. Related EDT No.:

$N / A$

7. Purchase Order No.:

N/A

9. Equip./Component No.:

$N / A$

10. System/Btdg./Facility:

305 Building

11. Receiver Remarks:

DATA TRANSMITTED

15.

\begin{tabular}{|l|l|l|} 
(A) & DATA TRANSMIT & (C)
\end{tabular}

\begin{tabular}{ll|l} 
Item & (B) Document/Drawing No. Sheet
\end{tabular}

No.

No.

No.

\begin{tabular}{l|l|l|l|l|}
\hline 1. & WHC-SD-WM-TP-263 & & 0 & $\begin{array}{l}\text { Elevated Drum Testing } \\
- \text { Phase I Test PIan }\end{array}$ \\
\hline & & & & \\
\hline & & & & \\
\hline
\end{tabular}

(E) Titlo or Description of Data

Transmitted

KEY

16.

Reason for Transmittal (G)

Approval Designator (F)

E, S, Q. D or N/A

(see WHC-CM-3-5.

Sec.12.7)

1. Approval

4. Review

5. Post-Roviow

3. information

6. Dist. (Receipt Acknow. Required)

SIGNATURE/DISTRIBUTION

(See Approval Designator for required signatures)

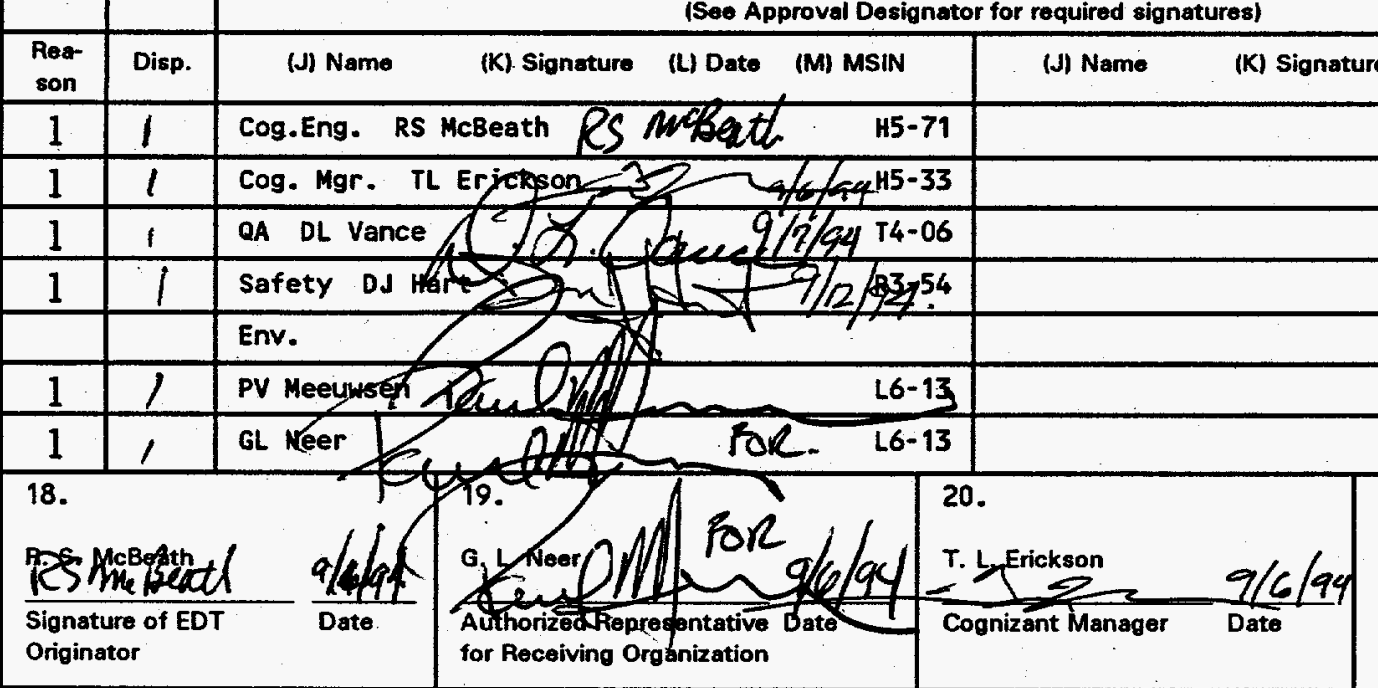

12. Major Assm. Dwg. Mo.: N/A

13. Permit/Permit Application No.: $N / A$

14. Required Response Date:

September 1, 1994

\begin{tabular}{|c|c|c|c|}
\hline (F) & $(\mathrm{G})$ & $(\mathrm{H})$ & $(\mathrm{I})$ \\
\hline $\begin{array}{c}\text { Approval } \\
\text { Desig- } \\
\text { nator }\end{array}$ & $\begin{array}{c}\text { Reason } \\
\text { for } \\
\text { Trans- } \\
\text { mittal }\end{array}$ & $\begin{array}{c}\text { Origi- } \\
\text { nator } \\
\text { Dispo- } \\
\text { sition }\end{array}$ & $\begin{array}{c}\text { Receiv- } \\
\text { er } \\
\text { Dispo- } \\
\text { sition }\end{array}$ \\
\hline $\mathrm{SQ}$ & 1 & 1 & 1 \\
\hline
\end{tabular}




\section{DISCLAIMER}

This report was prepared as an account of work sponsored by an agency of the United States Government. Neither the United States Government nor any agency thereof, nor any of their employees, make any warranty, express or implied, or assumes any legal liability or responsibility for the accuracy, completeness, or usefulness of any information, apparatus, product, or process disclosed, or represents that its use would not infringe privately owned rights. Reference herein to any specific commercial product, process, or service by trade name, trademark, manufacturer, or otherwise does not necessarily constitute or imply its endorsement, recommendation, or favoring by the United States Government or any agency thereof. The views and opinions of authors expressed herein do not necessarily state or reflect those of the United States Government or any agency thereof. 


\section{DISCLAIMER}

Portions of this document may be illegible in electronic image products. Images are produced from the best available original document. 


\section{RELEASE AUTHORIZATION}

Document Number: WHC-SD-WM-TP-263, REV. 0

Document Title: Elevated Drum Testing Phase 1 Test Plan

Release Date:

$9 / 15 / 94$

This document was reviewed following the procedures described in WHC-CM-3-4 and is:

APPROVED FOR PUBLIC RELEASE

****************

WHC Information Release Administration Specialist:

Andolis

(Signature)
N.L. SOLIS

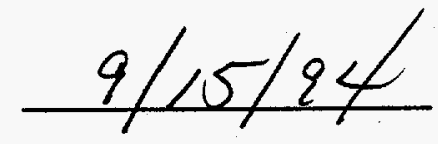

(Date) 


\begin{tabular}{|c|c|c|}
\hline $\begin{array}{l}\text { 2. Title } \\
\text { Elevated Drum Testing-Phase } 1 \text { Test Plan }\end{array}$ & $\begin{array}{l}\text { 3. Number } \\
\text { WHC-SD-WM-TP-263 }\end{array}$ & 4. Rev No. \\
\hline $\begin{array}{l}\text { 5. Key Hords } \\
\text { Drum Drop, Combustion, Stacking, Storage }\end{array}$ & \multirow{2}{*}{\multicolumn{2}{|c|}{$\begin{array}{l}\text { 6. Author } \\
\text { Name: RS McBeath } \\
\text { PV Meeuwsen } \\
\text { organization/Charge code } 87330 / 4 / 871\end{array}$}} \\
\hline 7. Abstract $9 / 15 / 94$ C. Sot/s & & \\
\hline 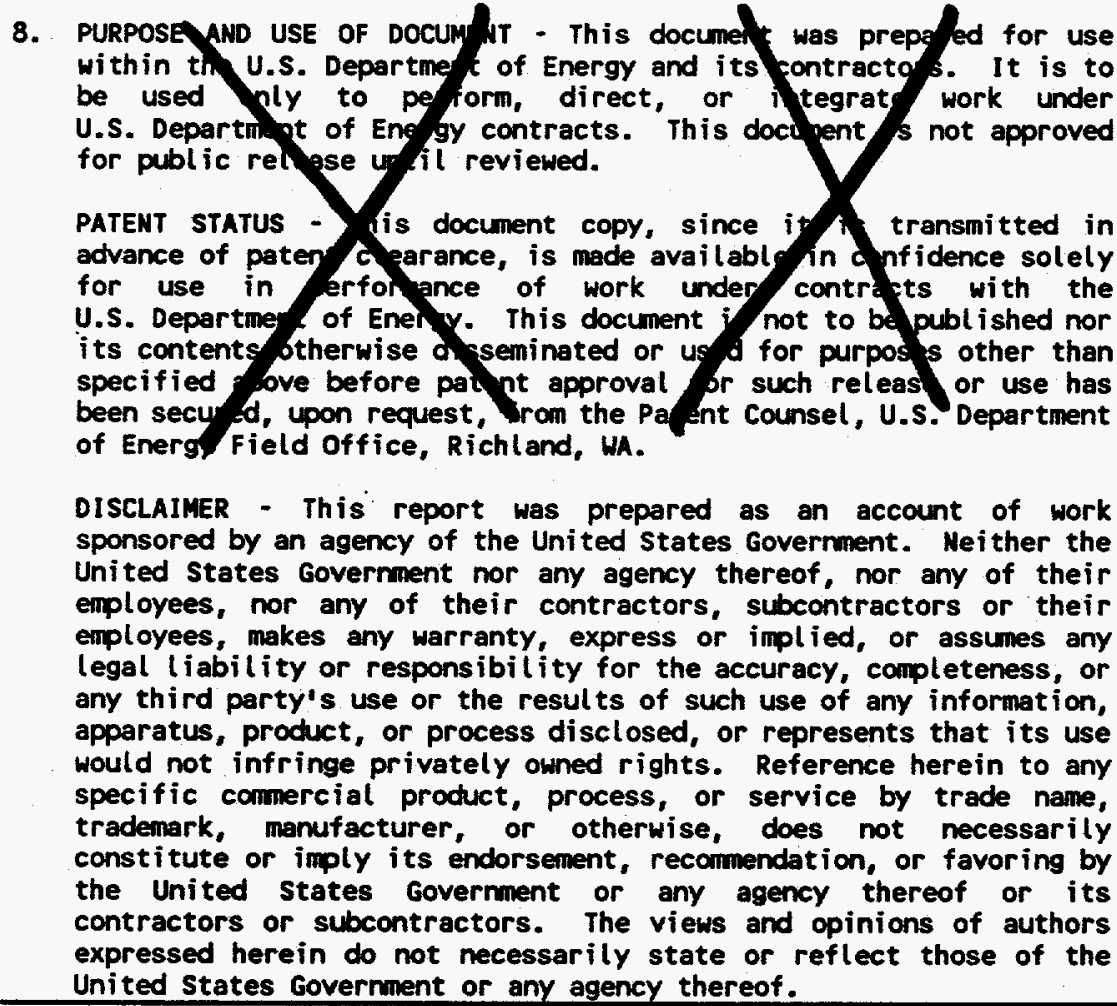 & $\begin{array}{r}\text { OFFICIAL RE } \\
\text { BYWHC } \\
\text { DATE SEP } \\
\text { Pta. }\end{array}$ & 199 \\
\hline 9. Impact Level SQ & & \\
\hline
\end{tabular}


WHC-SD-WM-TP-263

Revision 0

\section{ELEVATED DRUM TESTING \\ PHASE I TEST PLAN}

September 1, 1994

P. V. Meeuwsen

R. S. McBeath

Richland, Washington 
WHC-SD-WM-TP-263

Revision 0

Table of Contents

Page

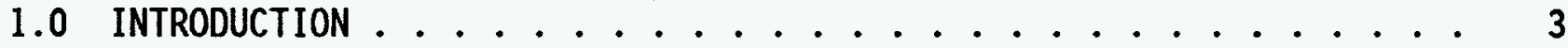

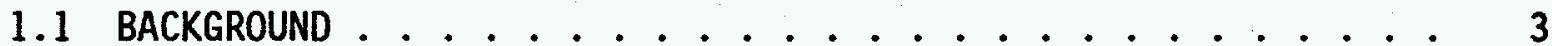

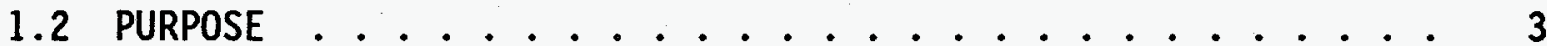

2.0 TEST DESCRIPTION . . . . . . . . . . . . . . . . 4

2.1 FACILITIES, EQUIPMENT, AND PERSONNEL . . . . . . . . . . 4

2.2 TEST EXCEPTIONS .................... . . . 4

2.3 TEST DATA .................... . . 4

2.4 TEST SEQUENCE .................... 4

2.5 TEST ARTICLE ........................ 4

2.6 TEST PROCEDURE ............................. 5

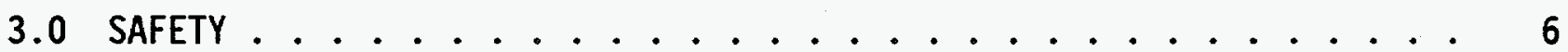

4.0 QUALITY ASSURANCE .................... 6

5.0 REFERENCES ......................... 7

APPENDIX A - CALIBRATION SHEETS ............... A-1

APPENDIX B - DATA SHEETS ................. B-1

APPENDIX C - SKETCH OF PALLET DROP MECHANISM ........... C -1 
WHC-SD-WM-TP-263

Revision 0

Elevated Drum Testing

Phase I Test Plan

\subsection{INTRODUCTION}

\subsection{BACKGROUND}

An important part of the Hanford environmental mission is the packaging, transportation, and storage of solid radioactive wastes in metal drums. Presently storage drums are placed four to a wooden pallet with the drums banded to each other. Palletized drums are stacked three units high in preengineered steel structures in the 200 Area of the Hanford site.

Storage space for drums in the Central Waste Complex (CWC) and the Waste Receiving And Processing Facility (WRAP) is limited. Permitted storage space is expensive to construct, maintain, and operate. Storage capacity is increased if additional drums can be stacked within existing facilities and a cost savings over new construction realized.

\subsection{PURPOSE}

The purpose of this plan is to outline the testing required to provide the safety criteria for elevated (i.e., tiers of four high) drum storage. Based on the "Central Waste Complex Waste Safety Analysis Report, FSAD Upgrade" (Cain, 1993), the major safety concern with elevated drum storage is the danger of a "significant" fire in the storage facility. The major fire load within the storage facilities is combustible material contained in the drums. If a seismic event, fork 1 ift accident, or other credible incident were to cause drum failure or lid separation, combustible material could be available for fuel.

The goal of this testing is to find if drums could be stacked four units high without increasing the potential fire load in the facilities. To increase the initial burn in the facilities, the drums must spill their combustible contents, making them free for ignition. If, through testing, it can be shown that there is not sufficient damage to the drums to allow for release of their solid contents, then the data used for safety documentation will be re-examined.

The testing described in this document will become the basis for the Safety Analysis Report (SAR) revision. The Phase 1 testing will support storage within the CWC and WRAP Facilities. Future Phase 2 testing will be conducted to support the W-112 automated stacker/retriever storage system and TRU Retrieval.

Preliminary tests conducted in the configurations detailed in this test $p l a n$ have shown that drums maintain their integrity; that is the drum covers remain attached and the drums do not breach. These tests will be conducted by 
Westinghouse Hanford Company, Equipment Development organization, who is the designated DOE Center of Excellence to conduct drop tests for Department of Transportation (DOT) certification of DOE designed packages and containers.

\subsection{TEST DESCRIPTION}

\subsection{FACILITIES, EQUIPMENT, AND PERSONNEL}

Al1 tests wi1l be conducted in the 305 Building. Drum drop tests will be performed on the unyielding drop pad in the 305 Building pit area. This drop pad is built to the Code of Federal Regulations (49 CFR) to certify DOT packaging.

Verification of all instrument and scale calibrations shall be performed prior to their use in the test. The calibration data shall be recorded in the area provided on the data sheet shown as Appendix $A$.

A11 testing will be conducted by Westinghouse Equipment Testing personnel. Westinghouse Quality Assurance shall provide oversight personnel. Test personnel will be trained and qualified in crane operation.

\subsection{TEST EXCEPTIONS}

This test sequence may be altered by approval of the Test Director (TD). Westinghouse Safety will approve changes to the test procedure if thought necessary by the TD. Any exceptions to the test procedure will be recorded in the space provide on the data sheet.

\subsection{TEST DATA}

Data collected during testing shall consists of completed data sheets (Appendix B), still photos, and video. Photographs and video will be marked "Information Only". All original data and documentation shall be maintained by Engineering Testing. Test article(s) will be stored at the 305 Building until the final test report is issued.

\subsection{TEST SEQUENCE}

Testing will be broken into four stages as outlined below.

STAGE I............DOT-17 C drum (55 gal), 132 in. drop STAGE II...........DOT-17 H drum (55 gal), 132 in. drop STAGE III.............4) DOT-17 C drums banded and on pallet (55 gal), 132 in. drop.

STAGE IV.............4) DOT-17 H drums banded and on pallet 55 gal), 132 in. drop. 
WHC-SD-WM-TP-263

Revision 0

\subsection{TEST ARTICLE}

The drums weights selected give the maximum energy to the dropped package. Less than $3 \%$ of waste drums weigh over $5001 \mathrm{bs}$ and 7 ess than $1 \%$ weigh over $1000 \mathrm{lbs}$. The average drum weight is $174 \mathrm{lbs}$.

The drop height of $132 \mathrm{in.}(11 \mathrm{ft}$ ) is $1 \mathrm{ft}$ higher than three drum/pallet stacks $\left(3 \times 40^{\prime \prime}=120^{\prime \prime}\right)$ supporting the fourth tier and is equal to the highest possible dropped drum in Project W-026, WRAP 1.

Each test configuration is repeated three times, the identical procedure used to qualify DOT certifications.

\section{STAGE I}

Drums used for Stage I testing will be D0T-17C, 55 gal drums. These drums shall be loaded with moist sand and lead bricks. Gross weight of each drum will be 1000 lbs. Three drums are required.

\section{STAGE II}

Drums used for Stage II testing will be DOT-17 H, 55 gal drums loaded the same as Stage I above. Three drums are required.

\section{STAGE III}

Four DOT-17C drums will be loaded on a wooden pallet and banded in a manner identical to the practices in the CWC. Two of the drums will be loaded to $500 \mathrm{lbs}$. gross weight, and two loaded to $174 \mathrm{lbs}$. gross weight. Load the pallet so that the heavier drums fall onto the lighter weight drums. The 175 1b. drums will be placed on the pallet so that their locking ring bolts will contact the drop pad at impact. Three pallets of four drums are required. The drop apparatus and rigging is shown in Appendix $C$.

A11 drums shall be closed with lid, gasket, locking ring, bolt, and nut. After loading the nut shall be torqued to $40 \mathrm{ft}$ ibs. No polyethylene bag liner will be used. Drums will be marked and identified for future reference.

\section{STAGE IV}

Stage IV testing will duplicate the Stage III tests except D0T-17H drums will be utilized. 


\subsection{TEST PROCEDURE}

\section{STAGE I}

Rig loaded Stage I drum I-001 so that the drum is 45 degrees to the drop pad. Position so that the drum falls on the locking ring bolt. Raise the drum so the lowest portion of drum is 132 in. from the drop pad surface. Release the drum and record data on provided sheet.

Inspect for cover attachment and the drum for breaches. Take sti11 photographs and video. Repeat using I-002 and I-003 drums.

\section{STAGE II}

Rig loaded Stage II drum II-00I so that the drum is 45 degrees to the drop pad. Position so that the drum falls on the locking ring bolt. Raise the drum so the lowest portion of drum is 132 in. from the drop pad surface. Release the drum and record data on provided sheet.

Inspect for cover attachment and the drum for breaches. Take still photographs and video. Repeat using II-002 and II-003 drums.

\section{STAGE III}

Rig the pallet drop apparatus. Load pallet with four loaded Stage III drums. Raise pallet so the bottom of the drums are horizontal and 132 in. from the drop pad. Release drums and record data provided sheets. Inspect for cover attachment and the drums for breaches. Take still photographs and video. Repeat test two times using eight new drums, pallets and banding.

\section{STAGE IV}

Rig the pallet drop apparatus. Load pallet with four loaded Stage IV drums. Raise pallet so the bottom of the drums are horizontal and 132 in. from the drop pad. Release drums and record data provided sheets. Inspect for cover attachment and the drums for breaches. Take still photographs and video. Repeat test two times using eight new drums, pallets, and banding.

\subsection{SAFETY}

All personnel shall wear appropriate safety equipment as directed by the Test Director. General shop safety per the "Westinghouse Industrial Safety Manual" (WHC-CM-4-3, Industrial Safety Manual) will be maintained at all times. The lead used as dummy payload is a known carcinogen and will be taken from the 305 Building lead supply and handled per 305 Building procedure. 


\subsection{QUALITY ASSURANCE}

Testing will be conducted under the Quality Assurance (QA) requirements as specified in the "Westinghouse Quality Assurance Manual" (WHC-CM-4-2, Quality Assurance Manual). Westinghouse QA personnel will be notified of the testing schedule and will observe.

\subsection{REFERENCES}

WHC-CM-4-2, Quality Assurance Manual, Westinghouse Hanford Company, Richland, Washington.

WHC-CM-4-3, Industrial Safety Manual, Westinghouse Hanford Company, Richland, Washington.

Cain, F. G., 1993, Central Waste Complex Final Safety Analysis Report, FSAD Upgrade, WHC-SD-WM-SAR-049, Rev. 0, Westinghouse Hanford Company, Richland, Washington.

49 CFR, Part 173.469, "Transportation," Code of Federal Regulations.

Sandia National Laboratory, 1983, Analysis, Scale Modeling, and Full-Scale Tests of Low-Level Nuclear-Waste-Drum Response to Accident Environments, SAND-80-2517, Sandia National Laboratories, Albuquerque, New Mexico. 
WHC-SD-WM-TP-263

Revision 0

APPENDIX A

CALIBRATION SHEETS

A-1 
WHC-SD-WM-TP-263

Revision 0

\section{CALIBRATION}

1

Equipment: Scale

Calibration Number

Calibration Date

2

Equipment: Torque Wrench

Calibration Number

Calibration Date

Equipment

Calibration Number

Calibration Date

4

Equipment

Calibration Number

Calibration Date 
WHC-SD-WM-TP-263

Revision 0

APPENDIX B

DATA SHEETS 
WHC-SD-WM-TP-263

Revision 0

\author{
DATA SHEET \\ STAGE I DOT-17 C drum (55 gallon), 132 inch drop \\ Stage I 001 drum
}

Verify 1000 pound (t/- 10 pounds plus tolerance on scale) gross weight. Record Void Volume:

Raise test article and verify 132 inch elevation QA TD

Start video. Drop on to locking ring bolt. Record data and photograph damage.

\title{
Test Results
}

Test Results/Data Recorded by: Date:

Describe and measure maximum deformation. Inspect for drum integrity.

\section{Exceptions}


WHC-SD-WM-TP-263

Revision 0

\author{
DATA SHEET
}

STAGE I DOT-17 C drum (55 gallon), 132 inch drop

Stage I 002 drum

Verify 1000 pound $(+/-10$ pounds plus tolerance on scale) gross weight. Record Void Volume:

Raise test article and verify 132 inch elevation QA $\quad / T D$

Start video. Drop on to locking ring bolt. Record data and photograph damage.

\title{
Test Results
}

Test Results/Data Recorded by:

Date:

Describe and measure maximum deformation. Inspect for drum integrity.

\section{Exceptions}


WHC-SD-WM-TP-263

Revision 0

\section{DATA SHEET}

STAGE I DOT-17 C drum (55 gallon), 132 inch drop

Stage I 003 drum

Verify 1000 pound (t/- 10 pounds plus tolerance on scale) gross weight. Record Void Volume:

Raise test article and verify 132 inch elevation $Q A$ $/ T D$

Start video. Drop on to locking ring bolt. Record data and photograph damage.

\section{Test Results}

Test Results/Data Recorded by:

Date:

Describe and measure maximum deformation. Inspect for drum integrity.

\section{Exceptions}


WHC-SD-WM-TP-263

Revision 0

\section{DATA SHEET}

STAGE II DOT-17 H drum (55 gal1on), 132 inch drop

Stage II 001 drum

Verify 1000 pound (t/- 10 pounds plus tolerance on scale) gross weight. Record Void Volume:

Raise test article and verify 132 inch elevation $Q A$ $/ T D$

Start video. Drop on to locking ring bolt. Record data and photograph damage.

Test Results

Test Results/Data Recorded by:

Date:

Describe and measure maximum deformation. Inspect for drum integrity.

Exceptions 
WHC-SD-WM-TP-263

Revision 0

\section{DATA SHEET}

STAGE II DOT-17 $\mathrm{H}$ drum (55 gallon), 132 inch drop

Stage II 002 drum

Verify 1000 pound (t/- 10 pounds plus tolerance on scale) gross weight. Record Void Volume:

Raise test article and verify 132 inch elevation. QA $/ T D$

Start video. Drop on to locking ring bolt. Record data and photograph damage.

\section{Test Results}

Test Results/Data Recorded by:

Date:

Describe and measure maximum deformation. Inspect for drum integrity.

Exceptions 
WHC-SD-WM-TP-263

Revision 0

\section{DATA SHEET}

STAGE II DOT-17 H drum (55 gallon), 132 inch drop

Stage II 003 drum

Verify 1000 pound (t/- 10 pounds plus tolerance on scale) gross weight.

Record Void Volume:

Raise test article and verify 132 inch elevation $Q A$ /TD

Start video. Drop on to locking ring bolt. Record data and photograph damage.

\section{Test Results}

Test Results/Data Recorded by:

Date:

Describe and measure maximum deformation. Inspect for drum integrity.

Exceptions 
WHC-SD-WM-TP-263

Revision 0

\section{DATA SHEET}

STAGE III DOT-17 C drum (4 Drums per pallet), 132 inch drop

Stage III, Pallet 1, Drums 001-004

Record gross weight for each drum. Place 4 drums on a pallet so that the heavy drums fall on to the lighter drums. Rotate the locking ring bolt of the lighter drums to the outside so that it contacts the drop pad at impact. Band the drums to the pallet and each other as performed at the Central Waste Complex.

Record Gross Weight of Each Drum: 1

2 3

Record Void Volume in Each Drum: 1 2 3 4

Raise test article and verify 132 inch elevation QA $/ T D$

Start video. Drop pallet on to pad. Record data and photograph damage. Test Results

Test Results/Data Recorded by: Date:

Describe and measure maximum deformation. Inspect for drum integrity. 
WHC-SD-WM-TP-263

Revision 0

\section{DATA SHEET}

STAGE III DOT-17 C drum (4 Drums per pallet), 132 inch drop

Stage III, Pallet 2, Drums 005-008

Record gross weight for each drum. Place 4 drums on a pallet so that the heavy drums fall on to the lighter drums. Rotate the locking ring bolt of the lighter drums to the outside so that it contacts the drop pad at impact. Band the drums to the pallet and each other as performed at the Central Waste Complex.

Record Gross Weight of Each Drum: 5 6 7 8

Record Void Volume in Each Drum: 5 6 7 8

Raise test article and verify 132 inch elevation QA TTD

Start video. Drop pallet on to pad. Record data and photograph damage.

Test Results

Test Results/Data Recorded by: Date:

Describe and measure maximum deformation. Inspect for drum integrity.

\section{Exceptions}


WHC-SD-WM-TP-263

Revision 0

\section{DATA SHEET}

STAGE III DOT-17 C drum (4 Drums per pallet), 132 inch drop

Stage III, Pallet 3, Drums 009-0012

Record gross weight for each drum. Place 4 drums on a pallet so that the heavy drums fall on to the lighter drums. Rotate the locking ring bolt of the lighter drums to the outside so that it contacts the drop pad at impact. Band the drums to the pallet and each other as performed at the Central Waste Complex.

Record Gross Weight of Each Drum: 9 10 11 12

Record Void Volume in Each Drum: 9 10 11 12

Raise test article and verify 132 inch elevation QA $/ T D$

Start video. Drop pallet on to pad. Record data and photograph damage.

Test Results

Test Results/Data Recorded by:

Date:

Describe and measure maximum deformation. Inspect for drum integrity.

Exceptions 


\section{DATA SHEET}

STAGE IV DOT-17 H drum (4 Drums per pallet), 132 inch drop

Stage IV, Pallet 1, Drums 001-004

Record gross weight for each drum. Place 4 drums on a pallet so that the heavy drums fall on to the lighter drums. Rotate the locking ring bolt of the lighter drums to the outside so that it contacts the drop pad at impact. Band the drums to the pallet and each other as performed at the Central Waste Complex.

Record Gross Weight of Each Drum: 1 2 3 4 Record Void Volume in Each Drum: 1 2 3 4

Raise test article and verify 132 inch elevation QA TTD

Start video. Drop pallet on to pad. Record data and photograph damage. Test Results

Test Results/Data Recorded by: Date:

Describe and measure maximum deformation. Inspect for drum integrity. 
WHC-SD-WM-TP-263

Revision 0

\section{DATA SHEET}

STAGE IV DOT-17 H drum (4 Drums per pallet), 132 inch drop

Stage IV, Pallet 2, Drums 005-008

Record gross weight for each drum. Place 4 drums on a pallet so that the heavy drums fall on to the lighter drums. Rotate the locking ring bolt of the lighter drums to the outside so that it contacts the drop pad at impact. Band the drums to the pallet and each other as performed at the Central Waste Complex.

Record Gross Weight of Each Drum: 5 6

Record Void Volume in Each Drum: 5 6 7 8

Raise test article and verify 132 inch elevation QA 7 8

Start video. Drop pallet on to pad. Record data and photograph damage. Test Results

Test Results/Data Recorded by: Date:

Describe and measure maximum deformation. Inspect for drum integrity.

Exceptions 
WHC-SD-WM-TP-263

Revision 0

\section{DATA SHEET}

STAGE IV DOT-17 H drum (4 Drums per pallet), 132 inch drop

Stage IV, Pallet 3, Drums 009-012

Record gross weight for each drum. Place 4 drums on a pallet so that the heavy drums fall on to the lighter drums. Rotate the locking ring bolt of the lighter drums to the outside so that it contacts the drop pad at impact. Band the drums to the pallet and each other as performed at the Central Waste Complex.

Record Gross Weight of Each Drum: 9 10 11 12

Record Void Volume in Each Drum: 9 10 11 12

Raise test article and verify 132 inch elevation

QA /TD

Start video. Drop pallet on to pad. Record data and photograph damage.

Test Results

Test Results/Data Recorded by: Date:

Describe and measure maximum deformation. Inspect for drum integrity.

Exceptions 
WHC-SD-WM-TP-263

Revision 0

\section{APPENDIX C}

\section{SKETCH OF PALLET DROP MECHANISM}




\section{Pallet Drop Mechanism}

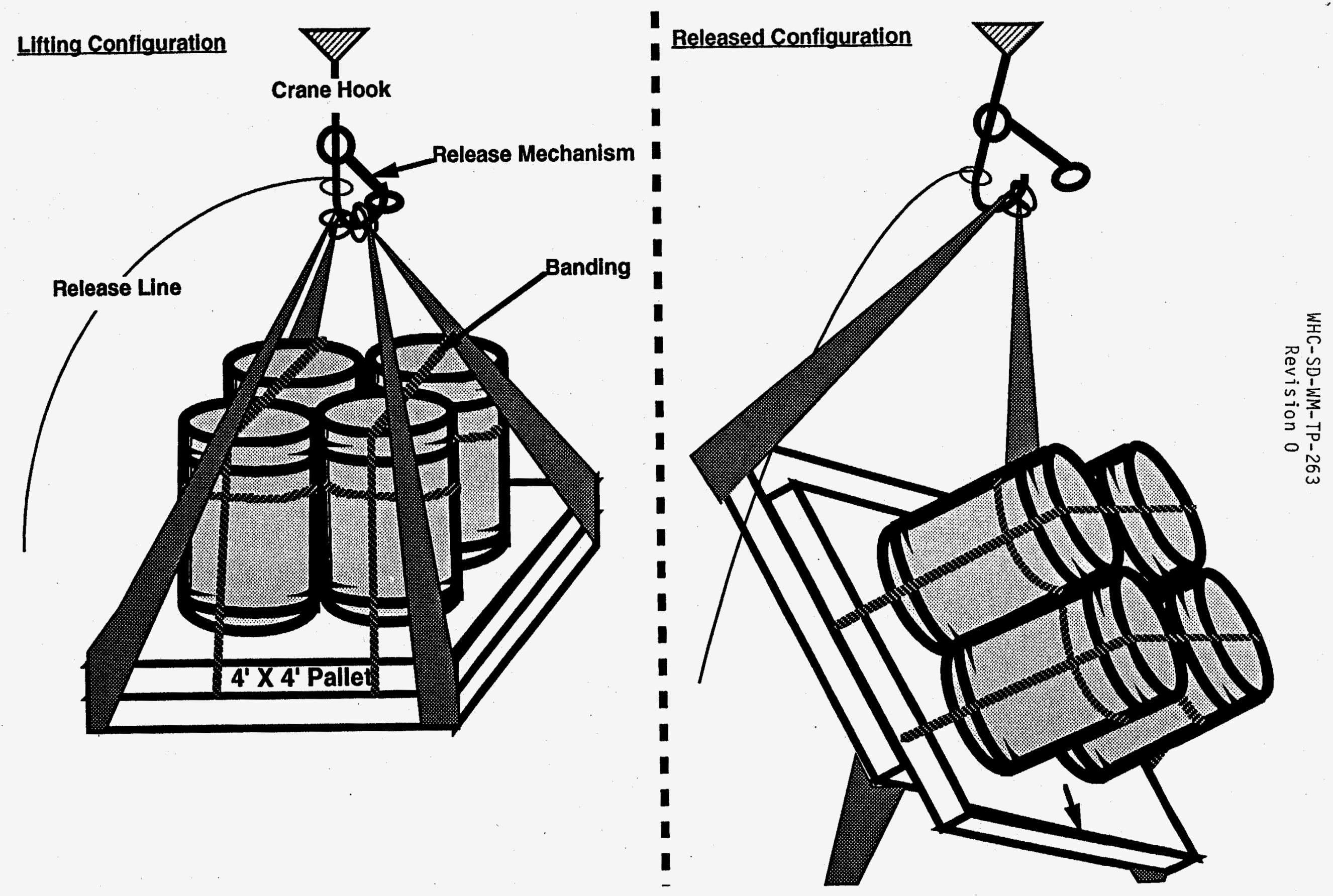

